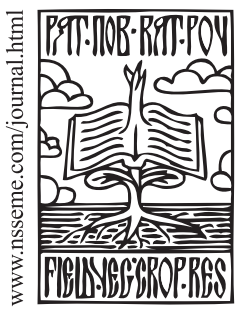

\title{
Relation among Different Parameters of Damaged Starch Content, Falling Number and Mechanical Damage Level
}

\author{
Dragan Živančev • Aleksandra Torbica • Jasna Mastilović • \\ Desimir Knežević • Nevena Đukić
}

received: 1 August 2012, accepted: 3 October 2012

(c) 2012 IFVC

doi: $10.5937 /$ ratpov49-2345

Summary: This work presents examination of damaged starch content expressed by different parameters, which were obtained by iodometric method presented by the Chopin Company using their SD matic instrument on wheat flour samples. Two wheat samples were similar by protein level (14.6 and 14.2\% on dry basis matter) and different by Falling number values (409 and $121 \mathrm{~s}$ ). Wheat flours were gained by single-stage and two-stage extraction in laboratory milling system. Eight independent measurements of every wheat flour sample were statistically analyzed by method of variance. It was found that Chopin iodometric method shows that damaged starch content expressed by different parameters is related to Falling number value and damage caused by the pressure and shear forces generated during roller milling. Key words: damage, falling number, milling, starch, wheat flour

\section{Introduction}

The compound with the highest share in wheat and especially in wheat flour is starch (approximately 63-72\%) from the kernel endosperm. It is biopolymer composed of amylose and amylopectin. The molecule of amylose is basically straight, composed of D-glucopyranosyl units connected with (1/4)$\alpha$ bonds. The size of amylose molecule ranges in regards to molecular weights from $10^{5}$ to $10^{6}$ (Lineback \& Rasper 1988). On the other side, amylopectin is characterized with simultaneous existence of (1/6)- $\alpha$-bond which connects string of approximately 20-25 D-glucopyranosyl units

D. Živančev* • A. Torbica • J. Mastilović

University of Novi Sad, Institute of Food Technology,

Bul. cara Lazara 1, 21000 Novi Sad, Serbia

e-mail: dragan.zivancev@fins.uns.ac.rs

\section{Knežević}

University of Priština, Faculty of Agriculture, Kopaonička bb, 38219 Lešak, Kosovo and Metohija, Serbia

\section{N. Đukić}

University of Kragujevac, Faculty of Natural Sciences, Radoja Domanovića 12, 34000 Kragujevac, Serbia linked through the (1/4)- $\alpha$-bond and because of that it has a branchy structure. Such structure results in the fact that amylopectin belongs to the group of the highest existing biopolymers $\left(>10^{8}\right)$. Usual content of amylose in wheat ranges from 25 to $28 \%$, whereas amylopectin share ranges from 72 to $75 \%$ (Colonna \& Buléon 1992). According to Lineback \& Rasper (1988), Evers et al. (1973) and Moon \& Giddings (1993) wheat starch consists of two different classes of starch granules. The first A-class is characterized with diameter above $10 \mu \mathrm{m}$ and shape similar to lenticular or disk. The diameter of the second class of starch granules B-class is under $10 \mu \mathrm{m}$ and their shape is approximately polygonal or spherical. Wheat

Acknowledgements: This material is based upon work supported by Ministry of Education, Science and Technological Development of the Republic of Serbia, Project III 46001 "Development and utilization of novel and traditional technologies in production of competitive food products with added value for national and global market CREATING WEALTH FROM THE WEALTH OF SERBIA" and bilateral cooperation between Serbia and Croatia "Genetic polymorphism of gluten proteins and its relationship to bread-making quality of wheat (Triticum aestivum L.)". Also, the authors are thankful to Mina Mitrović and MC Labor Company for providing SD Matic device for the study. 
starch is composed of approximately $70 \%$ granules A-class and 30\% granules B-class (Baum \& Bailey 1987). However, few scientists agree with Bechtel \& Wilson (2003) who classified wheat starch granules according to their size in three classes: large, medium and small (A-class, B-class and C-class, respectively). Maningat \& Seib (1997) showed that different classes of starch granules show notable diversity regarding amount of chemical compounds such as lipid and amylase, and they also reveal different pasting characteristics and bread making quality. Therefore their utilization is quite different. Starch which consists mostly of granules A-class is applied mainly in production of new materials such as biodegradable plastic and carbonless paper and granules B-class serve in food industry as a fat replacement (Nachtergraele \& Van Nuffel 1989).

It is well known that mechanic activities alter physical and chemical features of starch granules, their configuration and digestibility (Becker et al. 2001, Huang et al. 2007, Tester \& Morrison 1994). Also, extreme temperature and pressure may induce starch gelatinization in suspension composed of starch and water (Bauer \& Knorr 2005). The level of damage depends on kind of action and used force, starch origin (Becker et al. 2001, Tester \& Morrison 1994), wheat hardness (Hoseney 1994) as well as amylose and lipid content. Granules of damaged starch absorb water quickly and are excellent substrate for hydrolytic enzymes (Ranhotra et al. 1993). Level of water absorption of damaged starch is high (varies between 200\% and 430\%) and its disappearance leads to a decreasing of dough consistency (Barrera et al. 2007) and dough tenacity evaluated by alveograph (Brites et al. 2008).

In different types of cereal foods damaged starch can cause various effects. To some extent, presence of damaged starch is favourable in bread making process due to the effects of generation and acceleration of fermentation activity and optimization of water absorption (Boyac et al. 2004). Moreover, Tipples (1969) showed that application of high amounts of damaged wheat starch $(25-35 \%)$ in sponge dough procedure reduces level of bread staling, particularly when malt is included in the recipe. However, higher quantities of damaged starch evoke dough spreading because of water loss caused by amylase action. Bread loaf made of such dough is characterized with sticky crumb (Ranhotra et al. 1993). Gaines et al. (1990) showed that increased quantity of damaged starch results in decreased cookie dimensions. Prabhasankar et al. (2002) proved significant correlation between dough water absorption and damaged starch and that flour with the highest damaged starch made a softest chapatti. All above mentioned facts point out that damage starch has important influence on wheat processing properties and quality of wheat products.

Germination also has an important influence on cereal starch features due to alpha amylase activity that is efficient in starch degradation. Frias et al. (1998) showed that germination absolutely enhances the digestibility of starch granules by amylase. The swelling power and amylograph viscosity are reduced during germination (Lorenz et al. 1981). However, changes in level of amylose caused by germinated cereal kernels were not found (Frias et al. 1998). Sprouting of wheat kernels in the field due to heavy rains during harvest causes processing difficulties and drop of technological quality of wheat used in baking industry. Unfortunately, there are only some pieces of information on the properties of partly degraded starch formed by sprouting and activity of alpha amylase in wheat in the study of Dronzek et al. (1972) and researchers' efforts are now directed to investigation of pre-harvest sprouting tolerance (Jianga \& Xiao 2005, Biddulph et al. 2008, Van Eeden Labuschagne 2012).

Present study was undertaken in order to investigate relations of starch damage caused by mechanical forces during milling and by amylolytic activity in two wheat lines and 18 wheat varieties.

\section{Material and Methods}

Two wheat lines (sample 1 and sample 2) and 18 wheat varieties (Renesansa, NS Rana 5, Angelina, Simonida, Pobeda, NS 40S, Bastijana, Rapsodija, NS3-5299/2, Dama, Etida, Arija, Evropa 90, Kantata, Ljiljana, Zvezdana, Dragana and Vojvodina) were provided by Institute of Field and Vegetable Crops, Novi Sad, Serbia.

The wheat samples were milled to $60 \%$ flour yield on an MLU 202 (Bühler, Switzerland). Wheat flour of sample 1 and 2 were milled again by feeding reduction rolls which are tightened for one level. 
Falling number (FN) of the samples was determined following the ICC method 107/1, the different parameters of damaged starch (the absorption of iodine - Ai\%, damaged starch content in UCD - Chopin units, UCDc - Chopin units on protein basis matter, damage starch in AACC 76-31 (\%) - spectrophotometric method, damage starch in Farrand (\%) and velocity of iodine absorptions Vabs I 80\% (s)) was determined according to Chopin (France) iodometric method using SD Matic device in sample 1 and 2 in octuplicate, whereas in eighteen varieties in duplicate and mean values are calculated. Crude protein content $(\mathrm{PC})$ of wheat grain and flour on dry basis matter $[\mathrm{d} / \mathrm{m}]$ were determined according to ICC method 105/2.

The data were analysed by analysis of variance (ANOVA), the means were compared by the Duncan test at significance level of 0.05 using the Statistica 10.0 software.

\section{Results and Discussion}

Table 1 shows PC values of wheat and flour samples and FN values of wheat samples. Two wheat samples (sample 1 and sample 2) possess similar level of proteins (14.6 and $14.2 \%[\mathrm{~d} / \mathrm{m}]$, respectively). However, after milling PC of gained wheat flours were quite different (13.5 and 12.4\%). According to the FN values of two wheat samples (409 and $121 \mathrm{~s}$, respectively), alpha-amylase activity was not found in sample 1 , whereas in sample $2 \mathrm{FN}$ value was considerably $<200 \mathrm{~s}$.
The effect of repeated milling and tightening the reduction rolls for one level on apparent size flour particles is shown in table 2. As expected, the repeated milling of flour samples resulted in decreased particle size of flour samples. Moreover, after repeated milling 90\% flour particles of both samples were passed through the sieve with opening of $85 \mu \mathrm{m}$.

The statistical analyses revealed that five parameters measured by Chopins iodometric method (Ai\%, UCD, UCDc, damage starch in AACC 76-31 (\%) and damaged starch in Farrand (\%)) possess the same trend (Table 3). The smallest values of these five parameters were found in sample 1 obtained by usual milling. These values were statistically lower than values of damaged starch content of sample 2 obtained by usual milling, which showed low value of FN. These indicate that wheat varieties with low FN could possess high level of damaged starch content in wheat endosperm, which is in accordance with the results of León et al. (2006). Moreover, values of these five parameters in both samples obtained after repeated milling were statistically higher than flour sample 2 obtained by usual milling. It confirms the fact that tightening the rolls and increasing the rate of feed lead to an increase in the level of damaged starch content (Williams \& Fegol 1969). The differences in damaged starch content by both AACC 76-31 (\%) and Farrand (\%) parameters (Table 3) were larger between flours obtained by usual and repeated milling than between flours obtained from wheat

Table 1. PC of wheat and flour samples and values of wheat Falling number

\begin{tabular}{lccc}
\hline Sample & PC of wheat $(\%)[\mathbf{d} / \mathbf{m}]$ & PC of flour $(\%)[\mathbf{d} / \mathbf{m}]$ & FN $(\mathbf{s})$ \\
\hline Sample 1 & 14.6 & 13.5 & 409 \\
Sample 2 & 14.2 & 12.4 & 121 \\
\hline
\end{tabular}

Table 2. Particle size distributions of wheat flour samples obtained by usual milling and after repeated feeding reduction rolls which are tightened for one level

\begin{tabular}{lcccccc}
\hline \multirow{2}{*}{ Sample } & Type of milling & \multicolumn{5}{c}{ Sieve overtails (\%) on sieve opening of } \\
\cline { 3 - 7 } & & $150 \mu \mathrm{m}$ & $132 \mu \mathrm{m}$ & $105 \mu \mathrm{m}$ & $85 \mu \mathrm{m}$ & $<85 \mu \mathrm{m}$ \\
\hline \multirow{2}{*}{ Sample 1 } & usual milling & 3.2 & 2.8 & 21.8 & 26.5 & 46 \\
\cline { 2 - 7 } & repeated milling & 0.4 & 0.3 & 6.1 & 17.8 & 75 \\
\hline \multirow{2}{*}{ Sample 2 } & usual milling & 7.4 & 3.4 & 27.5 & 24.8 & 37 \\
\cline { 2 - 7 } & repeated milling & 0.2 & 0.1 & 9.8 & 25 & 65 \\
\hline
\end{tabular}


samples 1 and 2 which differentiated by FN. This observation indicates that the milling process is predominant cause of starch damage than damage which may come from the wheat itself (as a function of hardness) (Brites et al. 2008). However, velocity of iodine absorptions did not revealed statistical significance.

Values of FN and five parameters measured by Chopins iodometric method revealed the same trend in first two examined samples (Table 3) of
18 wheat varieties are represented in table 4. In four of them (Kantata, NS 40S, Etida, Ljiljana) values of FN were bellow $200 \mathrm{~s}$, whereas FN value of Dragana variety was slightly above the allowed minimum. Starch damage content of these varieties in UCDc units showed that only Kantata, Ljiljana and Dragana possess high values. Also, high values of FN above $300 \mathrm{~s}$ showed Arija, Vojvodina, and Evropa 90 varieties and two of them (Evropa 90 and Arija) possess

Table 3. Different parameters of damage starch content of wheat flour samples gained by usual milling and after repeated feeding reduction rolls which are tightened for one level

\begin{tabular}{lccccccc}
\hline Sample & Type of milling & AI\% & UCD & UCDc & $\begin{array}{c}\text { AACC } \\
\mathbf{7 6 - 3 1} \\
(\mathbf{\%})\end{array}$ & $\begin{array}{c}\text { Farrand } \\
\mathbf{( \% )}\end{array}$ & $\begin{array}{c}\text { Vabs I 80\% } \\
(\mathbf{s})\end{array}$ \\
\hline \multirow{2}{*}{ Sample 1 } & usual milling & $95,17^{\mathrm{a}}$ & $24,00^{\mathrm{a}}$ & $24,16^{\mathrm{a}}$ & $5,65^{\mathrm{a}}$ & $34,02^{\mathrm{a}}$ & 36,25 \\
& repeated milling & $96,29^{\mathrm{c}}$ & $27,34^{\mathrm{c}}$ & $27,51^{\mathrm{c}}$ & $6,60^{\mathrm{c}}$ & $45,80^{\mathrm{c}}$ & 31,38 \\
\multirow{2}{*}{ Sample 2 } & usual milling & $95,74^{\mathrm{b}}$ & $25,54^{\mathrm{b}}$ & $25,50^{\mathrm{b}}$ & $6,07^{\mathrm{b}}$ & $39,18^{\mathrm{b}}$ & 33,378 \\
& repeated milling & $96,61^{\mathrm{d}}$ & $27,88^{\mathrm{d}}$ & $27,85^{\mathrm{d}}$ & $6,76^{\mathrm{d}}$ & $47,90^{\mathrm{d}}$ & 33,67 \\
\hline
\end{tabular}

Mean values of quality parameters calculated on dry matter labelled by the same letter were not statistically significant $(\mathrm{p}<0.05)$.

Table 4. Different parameters of damage starch content of flour 18 wheat varieties and values of wheat FN

\begin{tabular}{lcccccc}
\hline Variety & AI\% & UCD & UCDc & AACC 76-31 (\%) & Farrand (\%) & FN $(\mathbf{s})$ \\
\hline Renesansa & $93.28^{\mathrm{a}}$ & $19.00^{\mathrm{a}}$ & $19.55^{\mathrm{a}}$ & $4,35^{\mathrm{a}}$ & $19,72^{\mathrm{a}}$ & $227,50^{\mathrm{f}}$ \\
NS Rana 5 & $93.86^{\mathrm{b}}$ & $20.50^{\mathrm{b}}$ & $20.80^{\mathrm{b}}$ & $4,72^{\mathrm{b}}$ & $23,62^{\mathrm{b}}$ & $268,75^{\mathrm{h}}$ \\
Pobeda & $94.10^{\mathrm{bc}}$ & $21.15^{\mathrm{bc}}$ & $21.60^{\mathrm{c}}$ & $4,89^{\mathrm{bc}}$ & $25,38^{\mathrm{bc}}$ & $216,00^{\mathrm{c}}$ \\
Angelina & $94.14^{\mathrm{c}}$ & $21.30^{\mathrm{c}}$ & $21.50^{\mathrm{c}}$ & $4,92^{\mathrm{c}}$ & $25,72^{\mathrm{c}}$ & $216,00^{\mathrm{c}}$ \\
Simonida & $94.28^{\mathrm{c}}$ & $21.65^{\mathrm{c}}$ & $21.55^{\mathrm{c}}$ & $5,02^{\mathrm{c}}$ & $26,78^{\mathrm{c}}$ & $227,25^{\mathrm{f}}$ \\
NS 40s & $94.54^{\mathrm{d}}$ & $22.35^{\mathrm{d}}$ & $22.20^{\mathrm{cd}}$ & $5,20^{\mathrm{d}}$ & $28,77^{\mathrm{d}}$ & $158,00^{\mathrm{b}}$ \\
Bastijana & $94.55^{\mathrm{d}}$ & $22.35^{\mathrm{d}}$ & $22.45^{\mathrm{d}}$ & $5,20^{\mathrm{d}}$ & $28,86^{\mathrm{d}}$ & $281,75^{\mathrm{i}}$ \\
NS3-5299/2 & $94.66^{\mathrm{de}}$ & $22.65^{\mathrm{de}}$ & $22.70^{\mathrm{de}}$ & $5,29^{\mathrm{de}}$ & $29,78^{\mathrm{d}}$ & $248,75^{\mathrm{g}}$ \\
Dama & $94.72^{\mathrm{de}}$ & $22.80^{\mathrm{def}}$ & $23.20^{\mathrm{ef}}$ & $5,32^{\mathrm{def}}$ & $30,20^{\mathrm{de}}$ & $297,25^{\mathrm{j}}$ \\
Rapsodija & $94.82^{\mathrm{ef}}$ & $23.10^{\mathrm{efg}}$ & $22.70^{\mathrm{de}}$ & $5,40^{\mathrm{efg}}$ & $30,69^{\mathrm{def}}$ & $283,25^{\mathrm{i}}$ \\
Etida & $94.93^{\mathrm{ef}}$ & $23.40^{\mathrm{fg}}$ & $23.25^{\mathrm{ef}}$ & $5,48^{\mathrm{fg}}$ & $31,97^{\mathrm{ef}}$ & $187,25^{\mathrm{c}}$ \\
Arija & $95.00^{\mathrm{e}}$ & $23.55^{\mathrm{g}}$ & $23.55^{\mathrm{fg}}$ & $5,53^{\mathrm{g}}$ & $32,60^{\mathrm{f}}$ & $418,75^{\mathrm{m}}$ \\
Kantata & $95.32^{\mathrm{g}}$ & $24.40^{\mathrm{h}}$ & $24.40^{\mathrm{h}}$ & $5,76^{\mathrm{h}}$ & $35,34^{\mathrm{g}}$ & $61,25^{\mathrm{a}}$ \\
Evropa 90 & $95.36^{\mathrm{g}}$ & $24.55^{\mathrm{h}}$ & $24.15^{\mathrm{gh}}$ & $5,79^{\mathrm{h}}$ & $35,74^{\mathrm{g}}$ & $305,50^{\mathrm{k}}$ \\
Zvezdana & $95.68^{\mathrm{h}}$ & $25.40^{\mathrm{i}}$ & $25.50^{\mathrm{i}}$ & $6,03^{\mathrm{i}}$ & $38,62^{\mathrm{h}}$ & $244,75^{\mathrm{g}}$ \\
Ljiljana & $95.72^{\mathrm{h}}$ & $25.50^{\mathrm{i}}$ & $25.30^{\mathrm{i}}$ & $6,06^{\mathrm{i}}$ & $38,96^{\mathrm{h}}$ & $192,25^{\mathrm{c}}$ \\
Dragana & $96.82^{\mathrm{i}}$ & $28.40^{\mathrm{j}}$ & $27.90^{\mathrm{j}}$ & $6,92^{\mathrm{j}}$ & $50,02^{\mathrm{i}}$ & $203,00^{\mathrm{d}}$ \\
Vojvodina & $97.06^{\mathrm{i}}$ & $29.05^{\mathrm{j}}$ & $29.05^{\mathrm{k}}$ & $7,12^{\mathrm{k}}$ & $52,69^{\mathrm{j}}$ & $319,25^{1}$ \\
\hline
\end{tabular}

Mean values of quality parameters labelled by the same letter were not statistically significant $(p<0.05)$. 
high values of starch damage content in UCDc units, which indicate that damage starch content probably depends on wheat variety, probably because of wheat hardness (Brites et al. 2008).

Significant differentiation of five parameters measured by Chopins iodometric method (Table 4) showed that using these method for measuring of damaged starch content in wheat samples is possible for good distinguishing level of starch damaging.

\section{Conclusions}

Present study revealed that wheat varieties with low $\mathrm{FN}$ values could possess high level of damaged starch level in wheat endosperm. Also, tightening the rolls leads to increased level of starch damage. However, influence of wheat varieties with low FN values on the level of damaged starch probably is not high as mechanical damage during milling. Moreover, level of damaged starch probably depends on wheat variety. Chopins iodometric method allows good distinguishing level of starch damaging in wheat samples.

\section{References}

Barrera, G.N., Pérez, G.T., Ribotta, P.D., \& León, A.L. (2007). Influence of damaged starch on cookie and breadmaking quality. Eur Food Res Technol, 225, 1-7.

Bauer, B.A., \& Knorr, D. (2005). The impact of pressure, temperature and treatment time on starches: Pressureinduced starch gelatinisation as pressure time temperature indicator for high hydrostatic pressure processing. J Food Eng, 68, 329-334.

Baum, B.R., \& Bailey, L.G. (1987). A survey of endosperm starch granules in the genus Hodeum: A study using image analytic and numerical taxonomic techniques. Can J Bot, 65, 1563-1569.

Bechtel, D.B., \& Wilson, J.D. (2003). Amyloplast formation and starch granule development in hard red winter wheat. Cereal Chem, 80, 175-183.

Becker, A., Hill, S.E., \& Mitchell, J.R. (2001). Milling - a further parameter affecting the Rapid Visco Analyser (RVA) profile. Cereal Chemistry, 78(2), 166-172.

Boyac, İ.H., Williams, P.C., \& Kökse, H. (2004). A rapid method for the estimation of damaged starch in wheat flours. J Cereal Sci, 39, 139-145.

Brites, C.M., dos Lourenço, S.C.A., Bagulho, A.S., \& Beirãoda-Costa, M.L. (2008). Efect of wheat puroindoline alleles on functional properties of starch. Eur Food Res Technol, 226, 1205-1212.

Colonna, P., \& Buléon, A. (1992). New insights on starch structure and properties. In: Cereal Chemistry and Technology: a Long Past and a Bright Future. Proceedings of the Ninth International Cereal and Bread Congress. $25-42$.

Dronzek, B.L., Hwang, P., \& Bushuk, W. (1972). Scanning electron microscopy of starch from sprouted wheat. Cereal Chem, 49, 232-239.
Evers, A.D., Greenwood, C.T.D., Muir, C.C., \& Venables, D. (1973). Studies on the biosynthesis of starch granules. Starch-Stärke, 26, 42-46.

Frias, J., Fornal, J., Ring, S.G., \& Vidal-Valverde, C. (1998). Effect of germination on physicochemical properties of lentil starch and its components. Lebensm Wiss Technol, 30, 178-183.

Gaines, C. (1990). Influence of chemical and physical modification of soft wheat protein on sugar-snap, cookie dough consistency, cookie size, and hardness. Cereal Chem, 67, 73-77.

Hoseney, R.C. (1994). Dry milling of cereals. In Principles of Cereal Science and Technology. (pp. 125-145). St. Paul, MN, USA: American Association of Cereal Chemists.

Huang, Z., Lu, J., Li, X., \& Tong, Z. (2007). Effect of mechanical activation on physico-chemical properties and structure of cassava starch. Carbohydrate Polymers, 68(1), 128-135. doi:10.1016/j.carbpol.2006.07.017

International Association for Cereal Science and Technology. (1991). Approved Standard Method No. 107/1. Vienna, Austria. 2nd edition.

León, A.E., Barrera, G.N., Pérez, G.T., Ribotta, P.D., \& Rosell, C.M. (2006). Effect of damaged starch levels on flour-thermal behavior and bread staling. Eur Food Res Technol, 224, 187-192.

Lineback, D.R., \& Rasper, V.F. (1988). Wheat carbohydrates. In Y. Pomeranz (Ed.), Wheat, chemistry and technology. (pp. 277-372). St. Paul. third ed.

Lorenz, K., Collins, F., \& Kulp, K. (1981). Sprouting of cereal grains: Effects on starch characteristics. Starch-Stärke,33, 183-187.

Maningat, C.C., \& Seib, P.A. (1997). Update on wheat starch and its uses. In: International wheat quality conference. Manhattan, KS, USA: Grain Industry Alliance.261-284.

Moon, M.H., \& Giddings, J.C. (1993). Rapid separation and measurement of particle size distribution of starch granules by sedimentation/steric field-flow fractionation. J Food Sci, 58, 1166-1171

Nachtergraele, W., \& van Nuffel, J. (1989). Starch as stilt material in carbonless copy paper-new developments. Starch-Stärke, 41, 386-392.

Prabhasankar, P., Manohar, R., \& Gowda, L.R. (2002). Physicochemical and biochemical characterization of selected wheat cultivars and their correlation to chapati making quality. Eur Food Res Technol, 214, 131-137.

Ranhotra, G.S., Gelroth, J.A., \& Eisenbraun, G.J. (1993). Correlation between Chopin and AACC methods of determining damaged starch. Cereal Chemistry, 70(2), 236-7.

Regulations on methods on physical and chemical analysis for quality control of wheat, milling and bakery products, pasta and fast frozen dough. Službeni list SFRJ, (1988). 74 , 1854-1887.

Tester, R.F., \& Morrison, W.R. (1994). Properties of damaged starch granules. V. Composition and swelling of fractions of wheat starch in water at various temperatures. Journal of Cereal Science, 20(2), 175-181.

Tipples, K.H. (1969). Relation of starch damage to the baking performance of flour. Baker's Digest, 43(6), 28-32.

Williams, P., \& Fegol, K. (1969). Colorimetric determination of damaged starch in flour. Cereal Chem, 46, 56-62. 


\section{Povezanost različitih pokazatelja sadržaja oštećenog skroba, broja padanja i nivoa mehaničkog oštećenja}

\section{Dragan Živančev • Aleksandra Torbica • Jasna Mastilović • Desimir Knežević • Nevena Đukić}

Sažetak: U ovom radu predstavljeno je ispitivanje sadržaja oštećenog skroba izraženog vrednostima različitih pokazatelja koji su dobijeni u uzorcima brašna jodometrijskom metodom na aparatu SD matic francuskog proizvođača Chopin. Dva uzorka pšenice su bila slična po nivou proteina (14,6 i 14,2\% na s.m), a razlikovala su se po broju padanja (409 i 121 s). Uzorci brašna su dobijeni jednostepenim i dvostepenim mlevenjem pšenice na laboratorijskom mlinu MLU 202. Vrednosti pokazatelja osam nezavisnih merenja svakog uzorka pšeničnog brašna su statistički obrađene metodom varijanse. Utvrđeno je da nivo sadržaja oštećenog skroba određen jodometrijskom metodom i izražen preko različitih pokazatelja zavisi od vrednosti broja padanja koji je indirektan pokazatelj amilolitičke aktivnosti, kao i pritiska i sila smicanja koji nastaju na valjcima laboratorijskog mlina.

Ključne reči: broj padanja, mlevenje, oštećenje, pšenično brašno, skrob 